\title{
Do postele s Kressidou
}

\section{Going to Bed with Cressida}

\author{
Eva Stehlíková
}

\begin{abstract}
Abstrakt
Studie o Malinově scénografii pro inscenaci Troila a Kressidy v Rajmontově režii v Činoherním studiu $\vee$ Ústí nad Labem 1979. Úspěch inscenace byl dán radikální úpravou textu, směřující k adaptaci, kterou Alex Koenigsmark přispěl k vyznění inscenace. Spojení Teiresia a Pandara do jedné postavy Kibice a potlačení antického plánu hry vyústilo do absolutního bezčasí. Rajmontova režie spolu s Malinovou scénografii pak dodala této "grotesce o militantní blbosti" všeobecnou platnost.
\end{abstract}

\section{Kličová slova}

inscenace, Shakespeare, Jaroslav Malina, Ivan Rajmont, Činoherní studio Ústí nad Labem

\begin{abstract}
A side note on Malina's stage setting for Rajmont's Troilus and Cressida production (Činoherní studio - Drama Studio, 1979). Its success was based on a radical modification of the text through which Alex Koenigsmark crossed the confines of a mere adaptation and significantly contributed to the shaping of the production. Joining Teiresias and Pandar into one character, namely that of Kibitzer, suppressing the ancient origins of the play, move it into an absolute timelessness. Rajmont's directing of this "grotesque about militant rubbish", as the scenographer, labelled the production, did not only relate straightforwardly to current reality and to demythologization of all values but it accomplished to get at a more general message.
\end{abstract}

\section{Keywords}

performance, Shakespeare, Jaroslav Malina, Ivan Rajmont, Činoherní studio Ústí nad Labem 
Hra Troilus a Kressida nepatří k často uváděným Shakespearovým opusům. Od roku 1921, kdy se hra dočkala první české premiéry v divadle na Vinohradech v rámci shakespearovského cyklu (režisér J. Kvapil, výtvarník A. Wenig), se na české scéně objevilo jen pouhých deset inscenací této hry. ${ }^{1}$ Všechna ztvárnění tohoto textu byla podrobována ostré kritice. Hra, o jejíž jevištní účinnosti se vždy pochybovalo (VODÁK 1921), byla kárána pro stylovou nevyhraněnost, špatnou stavbu, zdlouhavost, nejednoznačnost. Nakonec by asi všichni kritici podepsali „diagnózu“ stanovenou nad inscenací Davida Radoka (Národní divadlo Praha, 2012) - je to nejextrémnější a nejcyničtější Shakespearova hra, krutá a groteskní černá komedie, v níž „namísto udatného válčení sledujeme odpudivou změt podrazů, intrik a nabubřelého žvaněni“" (MIKULKA 2012). A nutno dodat: jen jedna z poválečných inscenací si získala skutečnou pozornost a byla oceněna kritikou a spontánně přijata obecenstvem, a to inscenace Ivana Rajmonta, která měla svou premiéru 11. ledna 1979 v Činoherním studiu v Ústí nad Labem. Přes nepřízeň dohlížejících orgánů se do své derniéry 29. června 1980 dočkala celkem 41 repríz.

Vracíme-li se k ní znovu právě ted’, má to svou logiku. Odešel Jaroslav Malina (19372016), poslední z tvůrců, kteří se na úspěchu této inscenace podepsali. Připomeňme ještě ty další nejdůležitější: Leoš Suchařípa (1932-2005), zaměstnaný v Činoherním studiu jako herec, ale ve skutečnosti podle Ivana Rajmonta „skutečný hnací motor veškerého dění“, Alex Koenigsmark (1944-2013), údajný adaptátor Shakespeara, ve skutečnosti autor „groteskní tragédie volně podle Shakespeara“, a Ivan Rajmont (1945-2015), umělecký šéf Činoherního studia v letech 1975-1986 a režisér této hry. Máme jediný cíl. Chceme zkoumat, čím se stalo, že se tato hra, o níž významný český shakespearolog napsal, že je to „hromada podivných postav a dějů“ (CHUDOBA 1941: 661), proměnila v inscenaci, která v normalizační šedi přinesla naději, že divadlo stále žije.

1 První poválečnou inscenací je v roce 1947 Kvapilova obnovená inscenace z nastudování v roce 1921 na Vinohradech. Další provedení se uskutečnilo až v Divadle Vítězného února v Hradci Králové v roce 1964, kde byl odvážně užit překlad Václava Renče, který se teprve roku 1962 vrátil z vězení (režie: Milan Pásek, scéna: Karel Zmrzlý, kostýmy: Miloš Patočka). První pražská inscenace se odehrála v roce 1966 v Divadle na Vinohradech (režie: Stanislav Remunda, výprava: František Tröster, překlad: E. A. Saudek a A. Skoumal). Po Rajmontově inscenaci z roku 1979, která je předmětem tohoto článku, pak následovaly ještě školní inscenace v divadelním studiu DAMU v Disku v roce 1984 (režie: František Štěpánek, výprava: Dana Hřivnová, překlad: J. V. Sládek), v Mahenově divadle v Brně v roce 1986 (režie: Zdeněk Kaloč, scéna: Jozef Ciller, kostýmy: Marta Rozkopfová, překlad: Jiří Josek), v Divadle KÁ v Praze v roce 1992 (režie: Petr Palouš, výprava: Milan Čech, překlad: Jiří Josek), v Klicperově divadle v Hradci Králové v roce 2001 (režie: Jakub Korčák, scéna: Ondřej Nekvasil, kostýmy: Zuzana Ježková, překlad: Jiří Josek), v Divadle Na zábradlí v roce 2006 (režie: Jiří Pokorný, scéna: Jan Štěpánek, kostýmy: Jana Preková, překlad: Jiří Josek). Poslední dosavadní inscenaci hostilo pražské Národní divadlo v roce 2012 (režie, výprava: David Radok, kostýmy: Zuzana Ježková, překlad: Martin Hilský). Databáze Divadelního ústavu nezahrnuje amatérské divadlo, tudíž v ní nelze najít informaci, že Koenigsmarkovu úpravu Troila a Kressidy hráli také ochotníci v Řevnicích v režii Radana Ruseva, který v Rajmontově inscenaci představoval Ajaxe (HIRSCHOVÁ 1980). K amatérským představením můžeme přidat ještě anglickou produkci studentů anglistiky FF UK v květnu 2003 v Roxy a brněnskou inscenaci souboru Stadec Dorost v únoru 2012 na půdě Stadionu na Kounicové. 
V době, kdy se Rajmont rozhodl pro text Troilus a Kressida, měl k dispozici ty překlady, které se už hrály: Sládkův, Renčův a Saudkův. ${ }^{2}$ Podle jeho vlastních slov by ale pouhá interpretace Shakespearova textu nestačila k naplnění jeho záměru (ŠVEJDA 2013: 80 na základě rozhovoru s Ivanem Rajmontem) a uvažoval proto o úpravě. Jenže Alex Koenigsmark, jeho př́ítel, který už s Činoherním studiem spolupracoval (rok před tím tu měla premiéru jeho hra Edessa), se nespokojil s pouhou úpravou, ale napsal ve skutečnosti nové drama, v němž zachoval ze Shakespearovy hry jen základní situace a některé postavy. V době, kdy experimentální scény jako Divadlo na provázku či Ypsilonka vyznávaly tak zvanou nepravidelnou dramaturgii, směřovalo Činoherní studio spíše k vytvoření vlastní divadelní dílny, jakou měl Činoherní klub a před tím už Národní divadlo v době Krejčova vedení, dále Krejčovo Divadlo za branou nebo Divadlo Na zábradlí. Alex Koenigsmark tak touto hrou vlastně přispěl i k částečné realizaci Rajmontovy touhy, kterou nakonec naplnil další „dvorní dramatik“, Karel Steigerwald (KÖNIGSMARK 2005).

Koenigsmarkova hra se původně jmenovala $V$ posteli s Kressidou, ale z taktických důvodů jí byl ponechán shakespearovský titul Troilus a Kressida a patrně z týchž důvodů byla odevzdána ke schválení první verze, která oznamuje, že „s použitím překladu E. A. Saudka upravil Alex Koenigsmark“. Tento text (jehož kopie existuje v knihovně Divadelního ústavu a v archivu ústeckého divadla) je ovšem podstatně odlišný od verze, kterou vydal autor až později pod názvem Noc s Kressidou (KOENIGSMARK 1993). Toto vydání údajně „odpovídá textu, který ČS hrálo“, což si „lze ověřit poslechem audiozáznamu představení“ (ŠVEJDA 2013: 78). Text a audiozáznam ovšem zdaleka nejsou totožné. Všechny změny směřují k podtržení hovorového charakteru dialogů. Jinak jsou změny spíše marginální a působí dojmem, že prostě zbyly z nějaké předcházející verze - tak např. Kressida je vyměněna nikoli za Kassandru, ale za Aenea. Ve zvukovém záznamu také Odysseus útočící na Achilla zmiňuje, že Achilles má pletky s Polyxenou. V Koenigsmarkově Noci s Kressidou o tom není ani zmínky. ${ }^{3}$ Zvukovému záznamu je nejbližší text zachovaný v pozůstalosti režiséra... Je tedy možné, že definitivní hranou verzi Koenigsmark pro knižní vydání ještě upravil a učinil více literární.

V době, kdy se inscenace úspěšně hrála nejen v Ústí, ale i při četných představeních v Praze, byl Koenigsmarkův text označován - částečně z opatrnosti, částečně z neznalosti - za adaptaci, ale už tehdy bylo konstatováno, že „Koenigsmarkova úprava textu Shakespearova Troila a Kressidy [...] je svým významem natolik podstatná, že lze hovořit

2 Přehled českých překladů Troila a Kressidy zahrnující i nevydané rukopisy a fragmenty viz (DRÁBEK 2012: 1093-1102).

3 Cesta od prvního Koenigsmarkova náčrtu k inscenované verzi byla patrně daleko komplikovanější. Ve své (nepublikované) seminární práci psané na semináři Milana Lukeše zmiňuje tehdejší posluchačka 2. ročníku, že kromě verze, kterou dnes označujeme jako první, je tu ještě další rukopisná verze nazvaná autorem Hra s posteli aneb Hektor, Troilus, Kressida atd. (SLOUPOVÁ 1981: 25-26). Možná, že ta byla základem inscenované verze, která vznikla „spoluprací všech členů souboru [...], inscenace jsou výsledkem nejužšího sepětí dramaturgické, režijní a herecké a ostatní umělecké práce“ (SLOUPOVÁ 1981: 18). 
o Koenigsmarkově podílu autorském na formování filozofie textu pro inscenaci“ (ŠORMOVÁ 1979: 18). Během práce na inscenaci došlo k mnoha podstatným změnám. Tou na první pohled nejzávažnější bylo sloučení postav Thersita a Pandara do jedné postavy nazvané Kibic, kterou uvedl v život a posléze i geniálně zahrál Leoš Suchařípa (KOENIGSMARK 2002). Sloučení postav vyvolala zdánlivě potřeba souboru, který neměl dostatek herců - ostatně už první verze má pouhých 15 z původních 28 postav, které uvádí Saudkův překlad. ${ }^{4}$

Zajímavé ovšem je, že právě Thersites je patrně jediná postava, která se do Shakespearova Troila a Kressidy dostala až z Homérovy Iliady. Ostatní „antické“ postavy evidentně s Homérem nesouvisejí. Jsou plodem dlouhé tradice, na jejímž počátku nestojí příslušný slepý pěvec (byt je často jmenován a citován), ale dva spisy pochybné kvality - Zápisky o válce trójské Diktyse Krétského a Pád Tróje Dareta Fryžského. Běžní diváci Shakespearovy doby stěží znali Homéra. ${ }^{6}$ Jejich znalosti o trójské válce se rekrutovaly z „překladů“ oblíbené středověké trojánské kroniky messinského soudce Quida z Columny, která vešla do mnoha jazyků - samozřejmě hned dvakrát do angličtiny (kroniky Lydgateova a Caxtonova) a dokonce dvakrát i do češtiny. ${ }^{7}$ Tento divák nevnímal trojskou historii jako cosi, co se odehrálo kdysi dávno a daleko, pro něho to byla prostě historie obleženého města, kterou znal z vlastní zkušenosti. Proto jeho srdce bilo na straně Trojanů (ostatně Británii údajně založil jistý trojský emigrant Brito!), byl důvěrně seznámen s jednotlivými hrdiny, znal i Troila, kterému Homér věnoval sotva jeden verš. Shakespearova hra pro něho nebyla persifláží homérských příběhů, tou se stala teprve později, když už byla středověká tradice mrtva. (Můžeme se ptát, kdo si u nás v poslední čtvrtině 20. století četl „o tom slavném městě Trojánském a o bojích, které jsú se staly“, jak se píše v české Trojánské kronice?) Tehdy začaly více vystupovat do popředí možné spoje mezi shakespearovskými a homérskými hrdiny. Pak se ze Shakespearovy hry stává ona hromada podivných postav a dějů - ovšem spíše pro intelektuální tvůrce než pro diváky, protože divák (a speciálně český divák) neměl v druhé polovině minulého století k Homérovi žádný vřelý vztah.

4 V seznamu osob je ovšem uvedeno jen 14 postav, omylem tu chybí Achilles.

5 Oba spisy česky viz Homérští hrdinové ve vzpomínkách věků. Přeložila Eva Kamínková. Praha: Svoboda 1972, členská prémie Antické knihovny.

6 Neřešíme otázku, kdy a kde se hra Troilus a Kressida prvně hrála. Pokud se ovšem předváděla pouze jako soukromé představení před studenty právnické fakulty (viz Joskův komentář v [SHAKESPEARE 2002: 5]), mohli bychom počítat snad i se vzdělanějším publikem, z něhož část mohla znát i originál a část Chapmanův překlad. Neřešíme ani otázky spojené se Shakespearovými inspiračními zdroji a ke komplikovanému putování trojského tématu (a vzniku postavy Kressidy z Briseidy a Chryseidy a Chaucerovy Kressidy), odkažme místo toho na následující stručnou a trochu ironickou charakteristiku: „Shakespeare’s bitter play is therefore a dramatization of part of a translation into English of the French translation of a Latin imitation of an old French expansion of a Latin epitome of a Greek romance.“ (HIGHET 1957: 55; tamtéž 50-55 i podrobný popis, viz též [DAŇHELKA 1951: 309-316])

$7 \quad \mathrm{O}$ velké oblibě kroniky na našem území svědčí rukopisné rozšíření ( 7 rukopisů), velmi brzké tiskové vydání prvního překladu (1468 pokládáno za inkunábuli) i pozdější krameriovské vydání v letech 1790, 1812, 1843 (DAŇHELKA 1951: 291-292). 
Koenigsmarkovo zakotvení příběhu v absolutním bezčasí podpořil výjimečně zdařilým způsobem i scénograf Jaroslav Malina, který se vystříhal jakýchkoli odkazů na $a$ tiku $^{8}$ a pro hrdiny hry vytvořil fantaskní kostýmy, jakési „kostýmní koláže válečníků, zneužívající převážně zdobné fragmenty parádních uniforem všech věků " (MALINA 2005: 70). Kostýmy jsou kupodivu symbolicky domyšleny. Troilus, Hektor a Paris - to jsou tři variace téhož ve třech decentních barvách: zelené, černé a červené. Přitom všechny tři postavy jsou normálně oblečeny. Řecký tábor je naproti tomu směsicí nejrůznějších prvků „nedourčeného“ oblečení hýřícího nejrůznějšími blýskavými cetkami - od Patroklových punčoch a kombiné přes Odysseův kabát oblečený na nahé tělo a Diomédovu oficírskou kazajku, která má sice epolety, ale postrádá jeden rukáv. Takové znaky má i kostým Heleny (je přece Řekyně) a přijímá je i Kressida přecházející do řeckého tábora, když zamění bílou řízu korespondující s barvou horizontu za barevný kostým děvky, kterému dominuje řízně zrzavá paruka. Kressida však zůstává „dooblečena“, protože není Řekyně, je Trójanka, stejně jako Kassandra, jejíž vyšinutost výtvarně dokumentují střevíce, které ovšem nemá na nohou, ale na šňưrce kolem krku. ${ }^{9}$ Kostýmy byly údajně příčinou konfliktu mezi režisérem a scénografem (MALINA 2005: 70). ${ }^{10}$ Herci však kostýmy přijali a scénická poznámka v Noci s Kressidou svědčí o tom, že mezi inscenátory nakonec panovala shoda: „Trojané jsou oblečeni jednoduše, vojensky. Řekové jsou pitoreskní banda, která táhla světem a kudy chodila, tudy kradla a všechno na sebe navlékala s barbarskou pestrostí." (KOENIGSMARK 1993: 119)

Koenigsmark zachoval Shakespearův sled scén. Vzhledem k tomu, že vypustil některé postavy (např. Agamemnona, Menelaa), muselo dojít i k některým dalším změnám trojskou misi do řeckého tábora vede Troilus, nikoli Aeneas, který tu rovněž vůbec nevystupuje. Na druhé straně Koenigsmark zase rozvedl Agamemnonovo vyprávění o tom, že Patroklus napodobuje jednotlivé hrdiny do scény, kterou režisér s hercem groteskně pojednají (mimochodem: tento Patroklus nezemře v boji, protože vůbec nebojuje). Nicméně zásahy do děje nebo do motivace postav jsou jen podružné. Stále platí: „All the argument is a cuckold and a whore“ (Troilus a Kressida 2.3.71; v Saudkově a Skoumalově překladu: „A jádro sporu: jeden paroháč a jedna kurva.“). Pásmo boje a lásky štavnatě komentuje Kibic přecházející bez problémů všemi bojišti a spílající oběma stranám.

8 Ty jsou latentně přítomny v inscenacích Kvapilových, pro něž Wenig vytvořil rozkošnou „barokní“ scenérii, jíž prosvítá pohled na athénskou Akropol, a nakonec i v inscenaci Radokově, v níž se snoubí typické vojenské šaty s náznaky antických kostýmů pod antickým tympanonem. Za pozornost by stálo i oblíbené používání „antických“ šněrovacích bot.

9 Nemohu se po létech už spolehnout na svou pamět, čerpám tedy z vlastní kritiky, která byla napsána na základě zhlédnutí dvou představení - 19. 1. a 27. 4. 1979 (STEHLÍKOVÁ 1979: 22). Viděla jsem v Žižkovském divadle ještě další dvě reprízy, ale už jsem o nich nepsala. Na poslední z nich jsem se setkala s významným shakespearovským znalcem Zdeňkem Stříbrným, který byl touto inscenací nadšen.

10 „Možná, že jsem se k němu choval příliš domahačně“, říká scénograf sebekriticky později (MALINA 2015: 70). V soukromém mailu ze dne 10. 5. 2016 doplnil: „Hodně jsme se kol toho všichni dohadovali, já jsem měl trochu problém s Ivanem, který poněkud znejistěl nad výtvarnem, ale to je na delší povídání, až se uvidíme." 


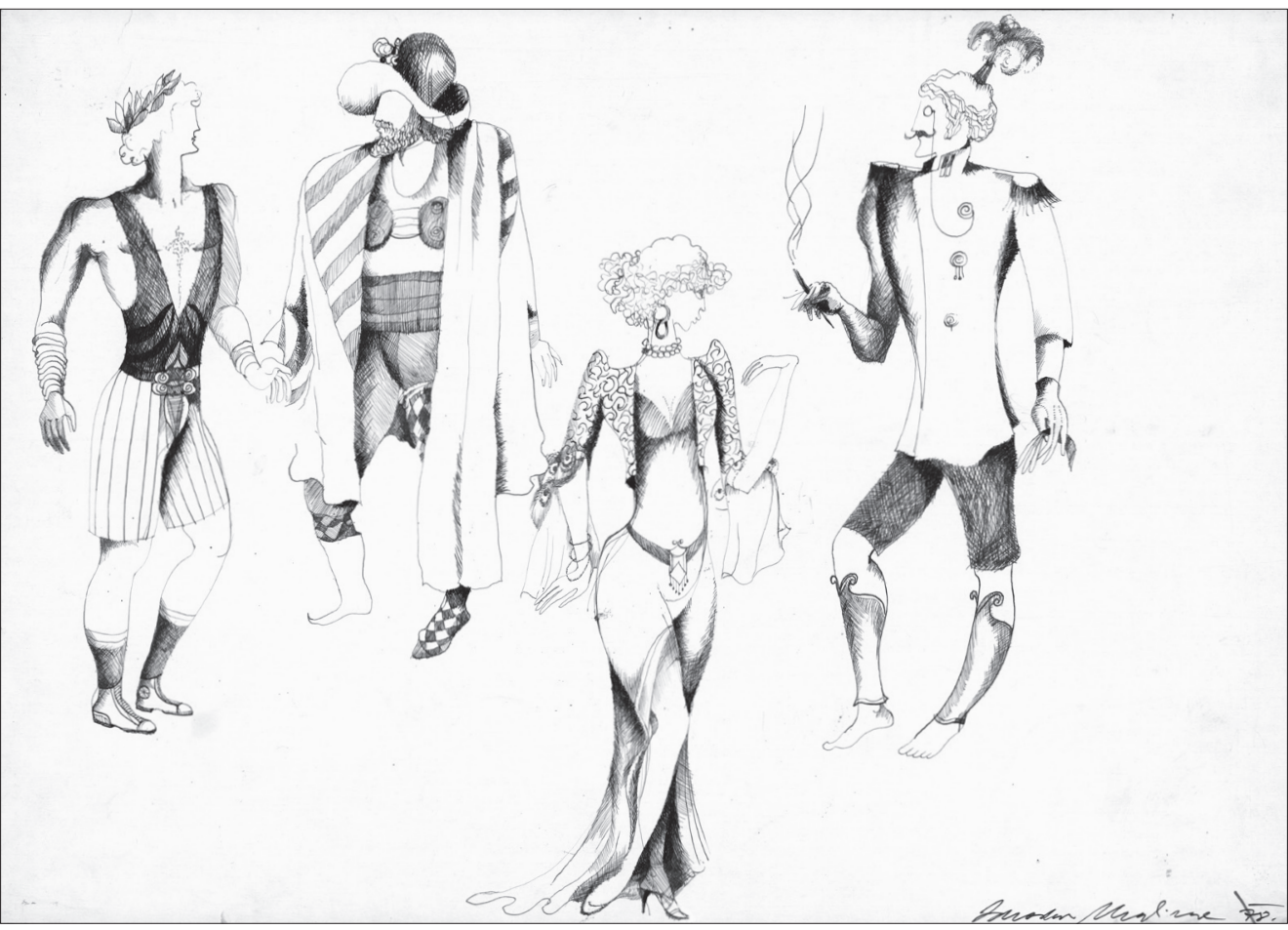

Obr. 1: Kostýmní návrhy k inscenaci (๔) Jaroslav Malina; zapůjčilo Divadelní oddělení Národního muzea v Praze)

Plynulý pohyb umožňovala Malinova antiiluzívní scéna ostře kontrastující s novobarokním interiérem měštanského ústeckého divadla. ${ }^{11}$ Uvnitř konvenčního divadla vytvořil Malina pomocí bílého plátna velkou oválnou, $\mathrm{k}$ divákovi otevřenou manéž. Bílý horizont tak prostor uzavíral a současně i otevíral průhledy do soukromí i do divadelního nekonečna. Jeviště se tím zvětšovalo nebo naopak zmenšovalo (FRYDLOVÁ 2012: 84). Nad hlavami herců a částečně i nad hlavami diváků byla zavěšena sít, „typický atribut manéže, sít zřejmě dlouho nepoužívaná a proto plná odpadků: cirkus je starý a zchudlý, válka už trvá devět let a bojišstě se stává smetištěm" (ČERNÝ 2005: 74). Pocit cirkusu navozoval i zvuk orchestrionu, který spolu s rykem bojovníků doprovázel celou hru.

Vybavení scény bylo víc než skromné - stará železná postel a špinavé matrace,$^{12}$ typické atributy tak zvané akční scénografie. Zbývá dodat, že Malina své akční scénografie poněkud „změkčuje“ právě hravým a básnivým užitím textilií. Ivanu Rajmontovi tato scénografie viditelně vyhovovala:

11 V době uvedení Troila a Kressidy se domovská scéna Činoherního studia restaurovala.

12 Jan Votruba si ve své obsáhlé kritice (VOTRUBA 1979) stěžuje na prach, který „vybuchuje po každém úderu matrací". 


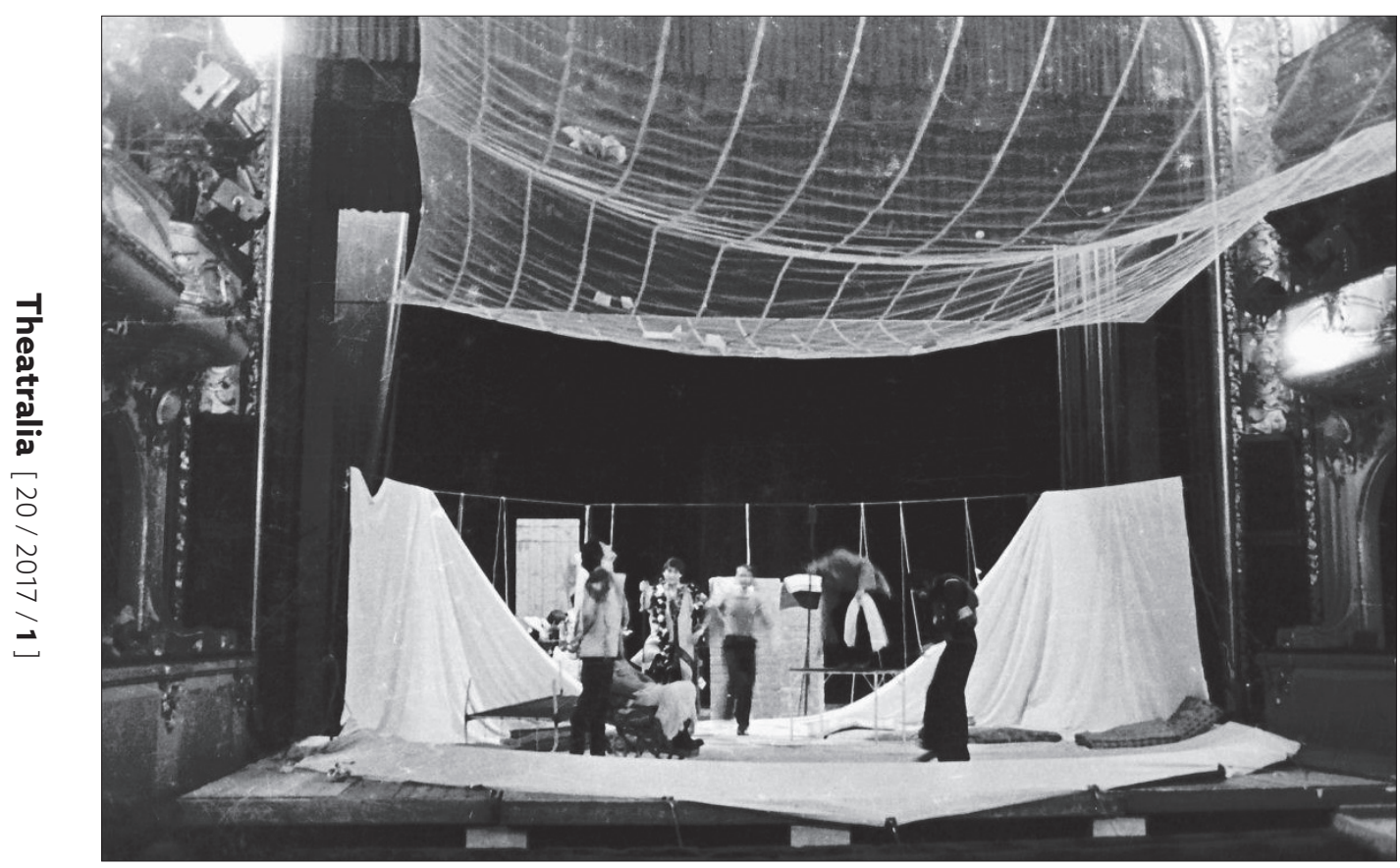

Obr. 2: Upoutání sítě ve Státním divadle Zdeňka Nejedlého (@ Vladimír Svoboda, foto poskytl Divadelní ústav v Praze)

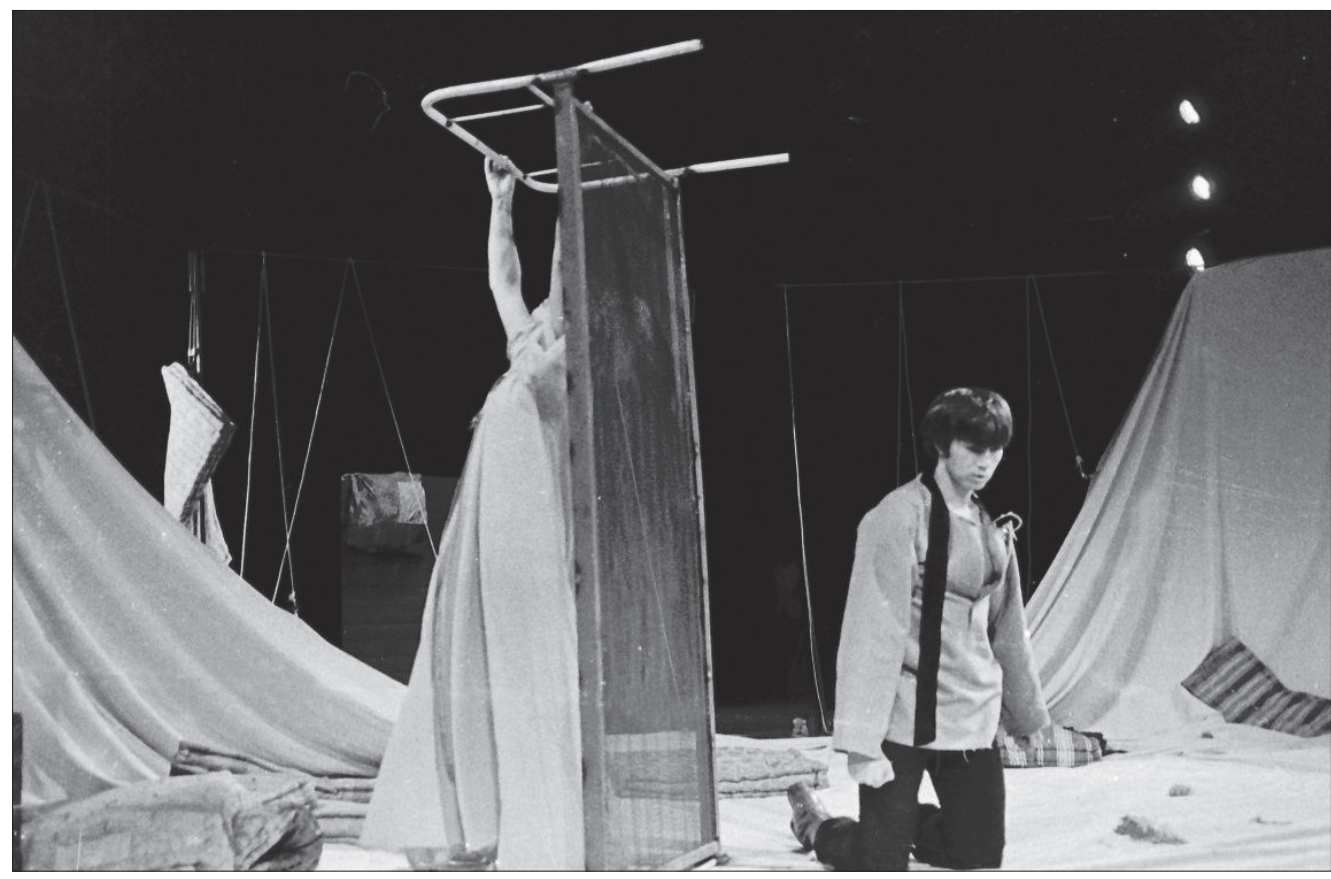

Obr. 3: Kressida (Jelena Šebestová) a Troilus (Jan Hrušínský) (๔ Vladimír Svoboda, foto poskytl Divadelní ústav v Praze) 


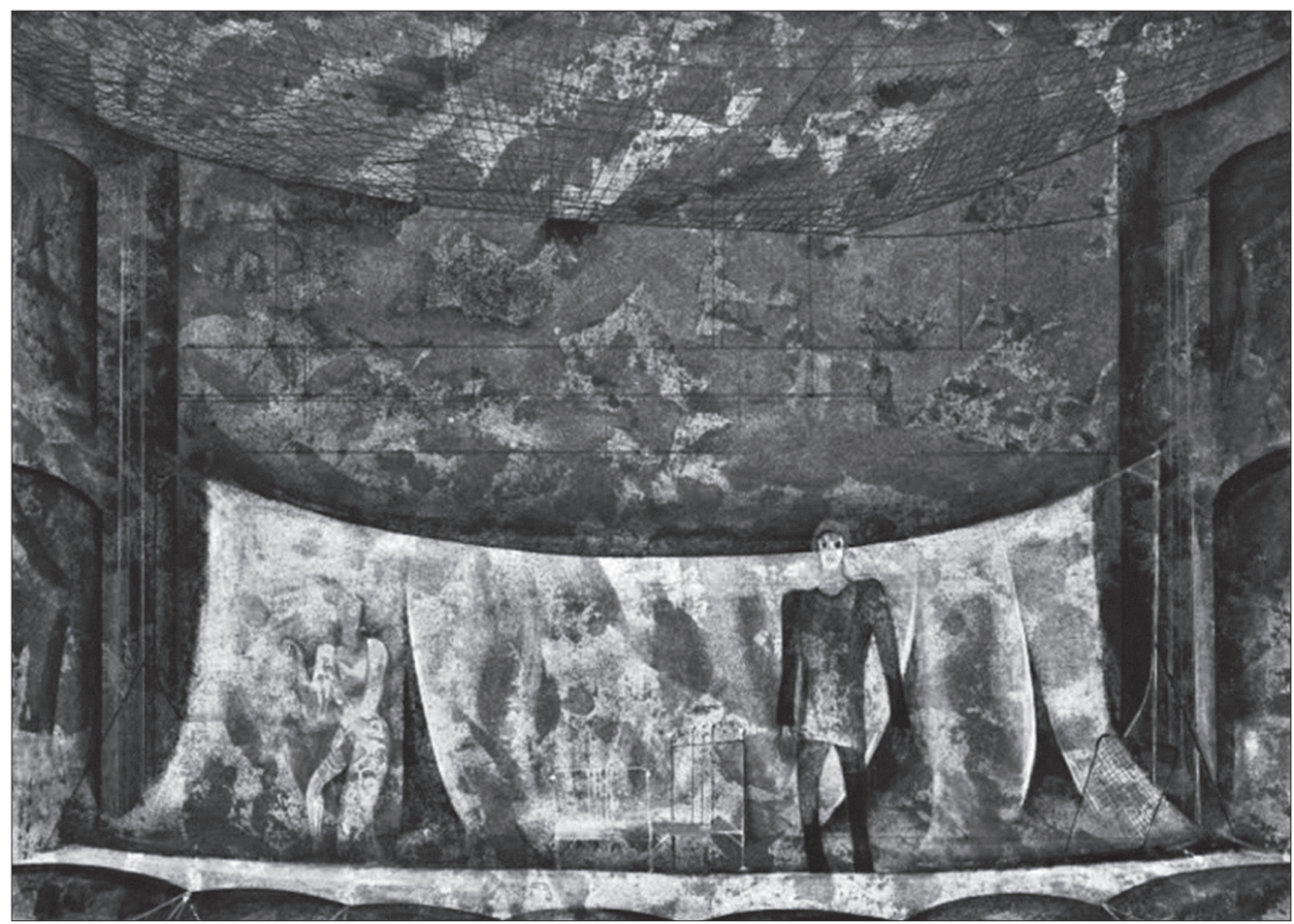

Obr. 4: Scénický návrh (@ Jaroslav Malina; foto poskytl Divadelní ústav v Praze)

V Jakubovi $i^{13}$ a Troilovi je vždy zachována realita věci samé: postel je vždy postelí a nikdy nezastupuje třeba stan. Ale způsob nakládání s tou postelí je metaforický: když se železná postel sklapne, nestává se sice vězením, ale když dva milenci k sobě nemůžou skrze mřížoví oné postele, tu se stává metaforou, zmnohonásobuje se její význam, věc tu prostě dostává nové funkce - aniž přestává být sama sebou. (RAJMONT 2005: 88)

Kdybychom měli k dispozici jen Malinův scénografický barevný plošný návrh - tuto jemnou a vzdušnou malbu na některých místech jemně kolorovanou, a tedy svým způsobem plastickou - asi bychom si jen stěží představili, co se na jeho scéně dělo. Přestože rozeznáme napjatou sít s odpadky, ve dvou lehce načrtnutých postavách můžeme vytušit Troila a Kressidu, identifikujeme i postel ukrytou za bílým horizontem. Pokud ovšem nepřijdou herci, kteří by do návrhu vnesli život, zůstane jen mrtvým obrazem, k němuž nemáme klíč.

Oživení a proměnění nejdůležitějšího scénického objektu, postele, o níž Kibic říká, že je to největší vynález všech dob, je mnohostranné, ale pokud slouží jen k odpočinku, lenošení, eventuálně milostnému spočinutí, je to objekt jen banální. Už režisér upozornil na to, co se stane, když mřrižoví postele od sebe oddělí oba milence. Ještě lépe

13 Jedná se o inscenaci textu Milana Kundery Jakub fatalista, který svým jménem „pokrýval“ Evald Schorm. Scénografem této hry byl Milan Palec. 
si to můžeme demonstrovat na scéně Hektorovy smrti. Koenigsmark v první verzi hry nenásleduje Shakespeara, který dává bezbrannému Hektorovi zahynout pod zbraněmi hordy Myrmidonů. Nezabije ho tedy osobně, zato chlubně prohlašuje: „Achilles hath the mighty Hector slain“ (Troilus and Kressida V, 8, v Saudkově a Skoumalově překladu „Achillem mocný Hektor byl dnes skolen“).

Abychom pochopili souvztažnost mezi textem a jeho režijním pojetím, věnujme se postupně dostupným variantám textu a srovnejme je s konečnou scénickou verzí.

Koenigsmarkův Hektor v první variantě textu znaveně usedne vyzván Achillem, společně odpočívají, pijí, hovoří o své únavě z války, o strachu ze smrti a z prázdnoty. Zdá se, že si oba nepřátelé mohou konečně pohovořit o tom, co je spojuje. Bohužel se ukáže, že nabídka k rozhovoru byla jen léčka. Achilles vyzve Hektora, aby se podíval, jak zapadá slunce. Scénická poznámka popisuje probíhající děj:

\section{Hektor (se podívá)}

Achilles (ho chladnokrevně zezadu podřizne, Hektor padne politý krví, zůstane ležet bez hnutí. Achilles otře nůž o jeho šaty a vstane) Řekové!

(Přrcházeji Řekové - Nestor, Ajax, Patrokles, za nimi Thersites, vzadu prícházi Odysseus s Kressidou, ale zatim je ostatni kryji)

Nestor Co se děje?

Achilles Vpřed, Řekové, ted' křičte všude kolem - že silný Hektor mnou byl právě skolen.

V Noci s Kressidou jde autor (nebo autoři) ještě dál. Podle scénické poznámky Achilles přichází beze zbraně s houslemi. Uvelebí se, napije se z láhve, brnká na housle. Vstoupí Hektor připraven k boji, Achilles ho však vybídne, aby rovněž usedl a odpočíval s ním. Tak jako v první variantě textu spolu hovoří o věcech, které je spojují.

Achilles Něco nad námi přece musí být. Podívej - slunce vychází...

(Hektor se ohlédne. Achilles ho uškrti strunou z houslí, kterou zatím sundal. Utře si ruce do Hektorovy košile. Opře mrtvého o postel, Hektorovi se z koutků vyřine krev)

Řekové, Řekové, volejte dokola: Achilles porazil Hektora!

Zajímavé je časové ukotvení. Zapadá slunce, nebo vychází? Bojuje se celý den, nebo celou noc? Přizpo̊sobili se inscenátoři v první variantě Shakespearovu textu? V obou případech jde o stejný věrolomný zločin. V tištěné verzi je navíc prohlouben tím, že Achilles přichází beze zbraně, čímž vytváří představu, že jde skutečně o mírumilovný, snad dokonce přátelský rozhovor. Oba rivalové mají přece stejné problémy - jsou unaveni válkou, jsou unaveni nenávistí.

V Rajmontově realizaci došlo k dalšímu posunu, který ještě vyhrotil brutálnost akce. Tento posun se odvíjí od scénografie. Hektor znaveně usedne, Achilles drnkající na housle stojí za ním. Zbabělá vražda mečem by pochopitelně byla stejně záludná, uškrcení 


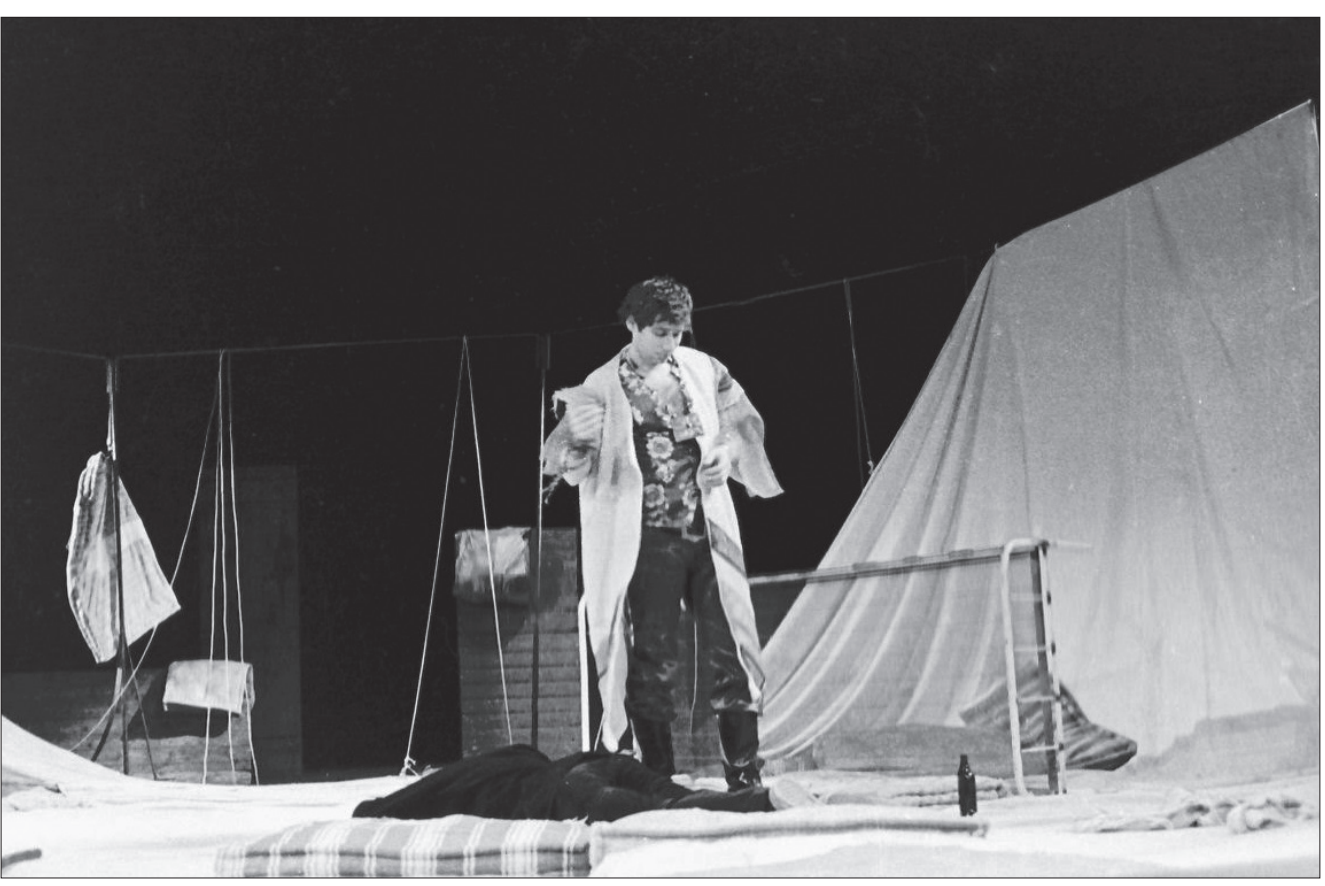

Obr. 5: Hektorova smrt (๔ Vladimír Svoboda, foto poskytl Divadelní ústav v Praze)

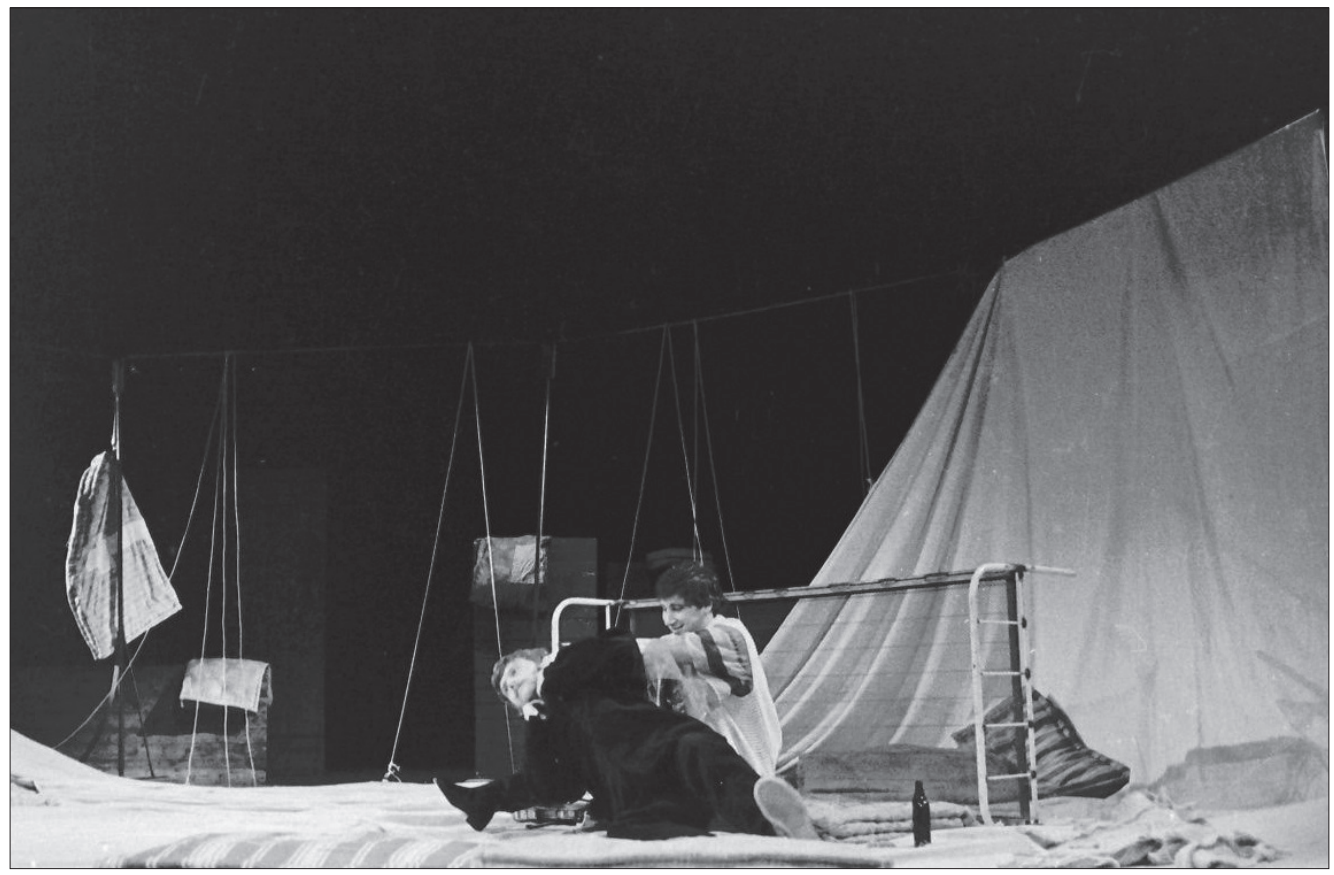

Obr. 6: Hektorova smrt (๔ Vladimír Svoboda, foto poskytl Divadelní ústav v Praze) 

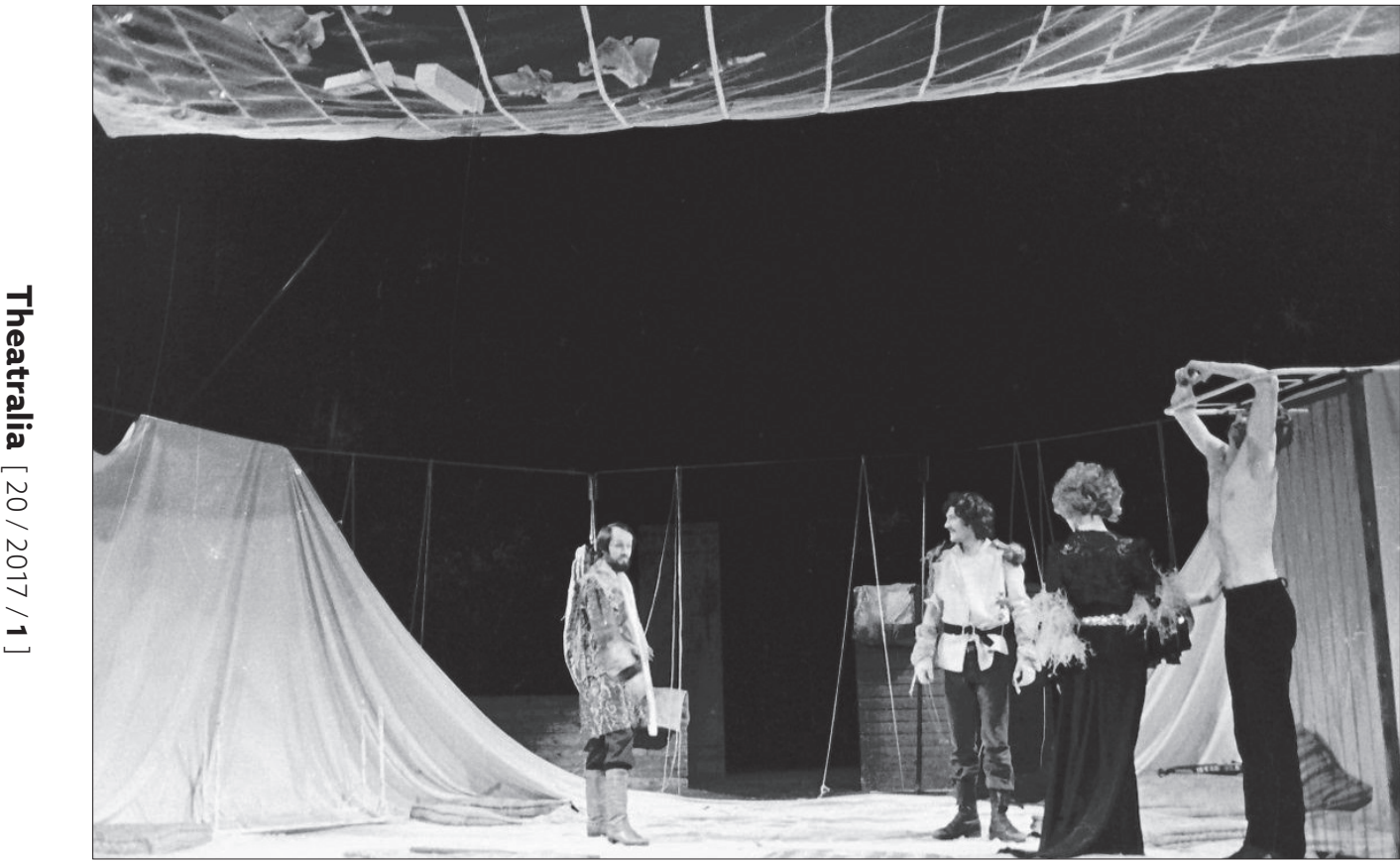

Obr. 7: Hektorova smrt (๔ Vladimír Svoboda, foto poskytl Divadelní ústav v Praze)

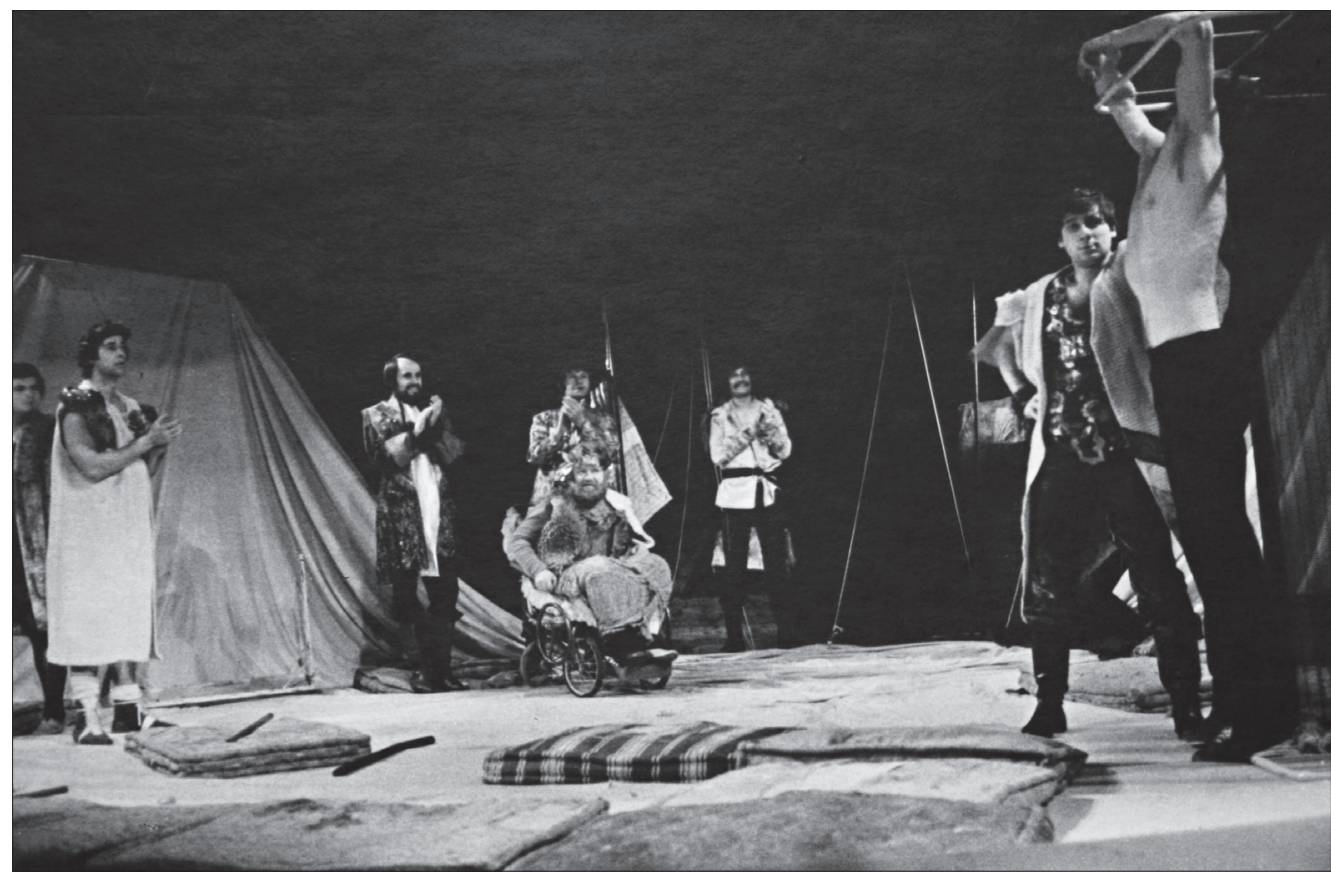

Obr. 8: Achilles (Tomáš Töpfer) předvádí Řekům zabitého Hektora (Jiří Schmitzler) (@ Vladimír Svoboda, foto poskytl Divadelní ústav v Praze) 
strunou z houslí je však zcela neočekáváné, proměna nástroje sloužícího k potěšení ve smrtící zbraň svědčí o tom, že tu vskutku žádná dohoda neplatí. Achilles pak mrtvého Hektora připoutá k posteli, která opodál leží na hraně své delší strany, poté postel zdvihne do vertikální polohy, takže Hektor na ní visí jako na řeznickém háku. Postel zůstala postelí, je místem pro milostnou něhu i válečnou brutalitu, stává se metaforou počátku i konce života. Přicházející Řekové spokojeně zatleskají, jako by šlo o divadelní výstup.

Rajmont se svými herci zcela přistoupil na poetiku ošklivosti, která beze zbytku vyjádřila odpor ke světu, v němž přestala platit všechna pravidla. Byla to, jak se vyjádřil scénograf, „velmi účinná groteska o militantní blbosti, na normalizaci jako dělaná“ (MALINA 2010). Přesto Rajmont neuzavřel divadelní svět do grotesky úplně.

Ve středu inscenace stála krásná, poetická scéna ložnicového setkání Troila a Kressidy... Ten záchvěv pravdy, který se tu rozezvučí, však patří k věci: i cirkus má takové momenty pravdy, kdy dechovka zmlká a akrobat v kopuli předvádí své salto mortale... Je zjevným záměrem úpravy a režijního plánu koncipovat Kressidu (i Troila) jako oběti, nikoli aktivní aktéry té cirkusové komedie. (ČERNÝ 2005: 77) ${ }^{14}$

Prostě i za takových okolností zůstává zrada zradou, podlost podlostí a smrt smrtí.

Jaroslav Malina považoval svou výpravu k Troilovi a Kressidě za nejcennější z těch, na nichž v Činoherním studiu pracoval (MALINA 2010). Sebezajímavější výprava by však zůstala mrtvým (a možná i nesrozumitelným) artefaktem, kdyby do ní nevstoupil režisér se svými spolupracovníky a svými herci. Ti vytvořili inscenaci, která přesáhla horizont malého ústeckého divadla. Ivan Rajmont řadil tuto inscenaci mezi ty, v nichž uskutečňoval svou divadelní konfesi (RAJMONT 2005: 89). Jeden z důvodů, proč se tato inscenace stala důležitým činem v kontextu celého českého divadla (Vp 1980), tkví v prostém faktu, že se při práci na inscenaci sešli lidé „spříznění volbou“. Ti v daném prostoru a za daných (často velmi obtížných) podmínek dokázali soustavně pracovat na určitém osobitém profilu divadla, na zcela určitém a svébytném inscenačním stylu. Vyprodaná představení i zachovaný zvukový záznam prozrazují, že obecenstvo svému divadlu dobře rozumělo.

14 Černý se opírá především o představení, v němž roli Kressidy hrála Kateřina Burianová. Ta byla, na rozdíl od Jeleny Šebestové s jejíma stále udivenýma očima a kočičí prrítulností, křehčí, subtilnější, obě však působily stejně zrazené, ponížené a uražené. Zradil je především Troilus, který - zcela v zajetí svých hloupých představ o válečné cti a své úloze - Kressidu nebrání a vydá Řekům. 


\section{Bibliografie}

ČERNÝ, Jindřich. 2005. Divadlo zdravého rozumu. Interní rozbor práce Činoherního studia přednesený před souborem z 12. 3. 1980 [Theatre of Common Sense. Internal analysis of the Činoherní studio productions, presented to the ensemble on 12 March, 1980]. Knižně [Published by]: TICHÝ, Zdeněk A. a kol. Ivan Rajmont - Režisér a jeho divadlo [Ivan Rajmont. The Director and His Theatre]. Praha: Pražská scéna, 2005: 72-86.

DAŇHELKA, Jiří. 1951. Poznámky a Doslov k vydáni Kroniky trojánské [Notes and Afterword to the Edition of the Trojan Chronicle]. Praha: Československý spisovatel, 1951.

DRÁBEK, Pavel. 2012. České pokusy o Shakespeara [Czech Attempts at Shakespeare]. Brno: Větrné mlýny, 2012.

ERML, Richard. 2002. Všechny nás zavřou. Záznam vzpomínek Ivana Rajmonta [We Will Be All Imprisoned. Record of Ivan Rajmont's Memories]. Divadelni noviny 11 (2002): 8-11; knižně [published by]: TICHÝ, Zdeněk A. a kol. Ivan Rajmont - Režisér a jeho divadlo [Ivan Rajmont. The Director and His Theatre]. Praha: Pražská scéna, 2005: 29-51.

FRYDLOVÁ, Veronika. 2012. Akčni scénografie v Československu [Action Scenography in the Czechoslovakia]. Praha. Diplomová práce [Diploma Thesis]. Univerzita Karlova. Filozofická fakulta. Ústav pro dějiny umění [Charles University, Faculty of Arts, Department of Art History].

GALLEROVÁ, Vlasta. 1984. Jaroslav Malina. Praha: Divadelní ústav, edice Režisér - Scénograf, sv. 13.

HIGHET, Gilbert. 1957. The Classical Tradition. Greek and Roman Influences on Western Literature. Oxford: Oxford University Press, 1957.

HIRSCHOVÁ, Eva. 1980. Troilus v Řevnicích aneb amatéři versus (plus) profesionálové [Troilus in Řevnice or The Amateurs versus (plus) the Professionals]. Mladá fronta Praha (13. 9. 1980).

CHUDOBA, František. 1941. Kniha o Shakespearovi [Book on Shakespeare]. Praha: Laichter, 1941.

KOENIGSMARK, Alex. 1993. Noc s Kressidou [Night With Cressida]. In Ponuré grotesky [Gloomy Slapstick Comedy]. Žd'ár nad Sázavou: Impreso Plus, 1993: 113-222.

KOENIGSMARK, Alex. 2002. Mezi židlemi aneb Hra na černocha III. [Between the Chairs or Playing a Blackman 3]. Divadelni noviny 11 (2002): 21.

KÖNIGSMARK, Václav. 2005. Rajmontova éra v ústeckém Činoherním studiu [Rajmont Era in the Činoherní studio Theatre in Ústí nad Labem]. In Zdeněk A. Tichý a kol. Ivan Rajmont - Režisér a jeho divadlo [Ivan Rajmont. The Director and His Theatre]. Praha: Pražská scéna, 2005: 103-111 (původně Činoherni studio DVACET LET [originally the Činoherni studio Theatre. TWENTY YEARS]). Ústí nad Labem: Klub přátel ČS, 1992: 81-82).

MALINA, Jaroslav. 2005. Očima scénografa [Through the Eyes of a Stage Designer]. In Zdeněk A. Tichý a kol. Ivan Rajmont - Režisér a jeho divadlo [Ivan Rajmont. The Director and His Theatre]. Praha: Pražská scéna, 2005: 67-70.

MALINA. Jaroslav. 2010. Nehodlám vyhánět staré dámy z divadla. Rozhovor scénografa s Janem Kolářem [I don't intend to drive old ladies out of the theatre. Interview with the stage designer]. Divadelni noviny 19 (28. 12. 2010): 22: příloha [supplement]: 1-6.

MIKULKA, Vladimír. 2012. Trojská válka ve Zlaté kapličce [The Trojan War in the "Golden Chapel”]. Respekt 23 (2012): 51-52: 70.

RAJMONT, Ivan. 2005. Nebýt ve vleku provozní káry. Nezveřejněný rozhovor vznikl pravděpodobně v sezóně 1983/84 pro publikaci Severočeského nakladatelství [“Not to Be Dragged By 
the Cart of Convention”. Unpublished interview probably given during the season 1983/1984 for a monograph of the Severočeské nakladatelství Publisher]. Viz [Cf.] TICHÝ, Zdeněk A. a kol. Ivan Rajmont - Režisér a jeho divadlo [Ivan Rajmont. The Director and His Theatre]. Praha: Pražská scéna, 2005: 87-95.

SHAKESPEARE, William. 1965. Troilus a Kressida [Troilus and Cressida]. Překlad E. A. Saudek (po smrti překladatele dokončil A. Skoumal) [Transl. by E. A. Saudek, finished post mortem by A. Skoumal]. Praha: Dilia, 1965.

SHAKESPEARE, William. 2002. Troilus a Kressida [Troilus and Cressida]. Překl. Jiřrí Josek [Transl. by Jiří Josek]. Praha: Romeo, 2002.

SLOUPOVÁ, Jitka. Seminární práce FF UK [Seminar Essay, Faculty of Arts, Charles University] 1981, v archivu režiséra [in the personal archive of the author].

STEHLÍKOVÁ, Eva. 1979. Troilus a Kressida [Troilus and Cressida]. Dialog 2 (1979-1980): 10: 20-22.

ŠVEJDA, Martin J. 2013. Ivan věděl, že mám žízeň po divadle. Alex Koenigsmark a Činoherní studio [Ivan Knew That I Thirsted For Theatre. Alex Koenigsmark and the Činoherní studio Theatre]. Divadelni revue (2013): 1: 74-91.

TICHÝ, Zdeněk A. a spol. 2005. Ivan Rajmont - Režisér a jeho divadlo [Ivan Rajmont. The Director and His Theatre]. Praha: Pražská scéna, 2005.

VODÁK, Jindřich. 1921. Troilus a Kressida [Troilus and Cressida]. Jeviště II (1. 2. 1921): 48; Čas (18. 12. 1921).

VOTRUBA, Jan. 1979. Od Shakespeara - kam? [From Shakespeare To - Where?] Průboj. Ústí nad Labem (3. 2. 1979).

Vp. 1980, posudek na inscenaci pořízený Divadelním ústavem, dokumentace Divadelního ústavu [Review For the Production by the Theatre Institute, in the archive of the Institute].

\section{Poděkování}

Autorka děkuje všem, kdo poskytli materiály nebo svými vzpomínkami osvěžili její pamět. Jsou to v abecedním pořádku: Helena Albertová, Pavel Drábek, Dagmar Haladová (Činoherní studio Ústí nad Labem), Milada Pravdová Malinová, Kateřina Šavlíková, Jan Hrušínský, Jitka Sloupová, Denisa Štastná (oddělení dokumentace Divadelního ústavu), Tomáš Töpfer. 


\section{Prof. PhDr. Eva Stehlíková}

Katedra divadelních studií,

Filozofická fakulta, Masarykova univerzita

stehlice@gmail.com

Prof. PhDr. Eva Stehlíková (1941) přednáší na FF MU v Brně (ČR), specializace: antické a raně středověké divadlo, novodobé inscenace antického dramatu, problematika intertextuality.

Eva Stehlíková (1941) has a position at the Department of Theatre Studies, Faculty of Arts, Masaryk University in Brno (Czech Republic). The fields of her scholarly interests include Classical and Early Medieval theatre, modern productions of Classical drama, and intertextuality. 